\title{
Potential costs and benefits of marine reserves in the high seas
}

\author{
Ussif Rashid Sumaila*, Dirk Zeller, Reg Watson, Jackie Alder, Daniel Pauly \\ Fisheries Centre, University of British Columbia, 2202 Main Mall, Vancouver, British Columbia V6T 1Z4, Canada
}

\begin{abstract}
The issue of conservation and sustainable use of high seas resources is increasingly becoming significant, as is reflected in the number of planned international activities in ocean science and management, e.g. the United Nations General Assembly Working Group on marine bio-diversity beyond national jurisdiction. Essentially, the increasing exploitation pressure on high and deep sea resources makes discussion of viable policy options for international waters an important topic. To our knowledge, this paper provides the first global, economically supported assessment of the impact on fisheries of potentially protecting a portion of the high seas in no-take marine protected areas. Such closures are likely to result in relatively little global annual profit loss. For example, closure of $20 \%$ of the high seas may lead to the loss of only $1.8 \%$ of the current global reported marine fisheries catch, and a decrease in profits to the high seas fleet of about US\$270 million per year. Thus, at globally minimal costs, the international community could benefit substantially by securing insurance against extinctions and the loss of the spectacular marine diversity in the high and deep seas, while protecting many market and non-market values for the benefit of both current and future generations.
\end{abstract}

KEY WORDS: Fisheries $\cdot$ RFMOs $\cdot$ Economics $\cdot$ Future generations

Resale or republication not permitted without written consent of the publisher

\section{INTRODUCTION}

Many of the fisheries in crisis today are inshore and within countries' Exclusive Economic Zones (EEZ), which usually extend 200 nautical miles (n miles) from shore (Pauly et al. 2002). Fisheries on the high seas, which constitute about $56 \%$ of the entire world's ocean area, have yet to reach the same state. Nevertheless, there is evidence of overfishing of the fishery resources in the high seas as excess capacity spills farther offshore to fill the supply gap from overfished, dwindling, and in some cases more cautiously managed shelf and EEZ resources. This is particularly evident for the socalled 'deep-sea' fisheries (e.g. Gjerde \& Freestone 2004). While excessive depletion in pelagic or open water fisheries has also been suggested, e.g. by Myers $\&$ Worm (2003), their analysis and conclusion has been challenged on analytical grounds (e.g. Walters 2003). In any event, the global challenge is how to avoid the 'Tragedy of the Commons' (Hardin 1968), where many nations claim the right to participate freely and unhin- dered in utilizing the resources of the high seas, which has been shown to ultimately lead to overfishing.

High seas fisheries governance (the term 'governance' is understood here to describe the processes, mechanisms, and institutional structures that establish the legal authority or mandate to conserve and manage fisheries resources, and the decision-making frameworks that exist within such institutional structures) is problematic because these resources remain global commons - they exist as residual domains beyond territorial seas and EEZs of coastal states as established by the United Nations Convention on the Law of the Sea (UNCLOS, Fig. 1). Efforts since UNCLOS, such as the Fish Stocks and Compliance Agreements, resulted in the development of a complex and evolving web of binding and non-binding international instruments, with the objective of balancing conservation of the resources of the high seas and the interest of individual states in the use of these resources (United Nations 2005). Currently, attempts to achieve sustainable management of high seas fish- 
eries have been primarily through the development of Regional Fisheries Management Organizations (RFMOs) targeting cooperative management between those who choose to participate (Lodge 2004).

Generally, all of these efforts have so far not resulted in sustainable fishing, for reasons including the following: (1) RFMOs that are being relied upon as the guarantors for sustainability of high sea fisheries have limited powers to enforce their rules; (2) global coverage of RFMOs is a mosaic of managed fisheries (www.fao. org/fi/body/rfb/index.htm), with some RFMOs managing a multitude of fisheries, while others manage just a few specialized fisheries; (3) the 'free riders', i.e. states that choose not to join RFMOs, continue to fish outside of RFMO rules, and thus undermine the conservation measures; (4) fishers register (or re-flag) their fishing vessels in states that are not members of the RFMOs concerned and continue to exercise their (claimed) freedom to fish on the high seas unrestricted by the conservation measures set by the RFMOs; (5) illegal, unreported, and unregulated (IUU) fishing is widespread on the high seas (High Seas Task Force 2006); (6) the huge subsidies being paid to the fishing sector in many countries fuel fishing on the high seas (Sumaila \& Pauly 2006); and (7) it is simply too expensive to monitor the currently existing wide array of diverse management strategies.

\section{A BOLD PROPOSAL}

To address some of these problems, we suggest that a portion of the high seas should be set aside as marine reserves. Whether considerations ought to be given to differentiating pelagic from deep-sea fisheries closure needs may depend on a number of factors, including currently ongoing spatial assessments of global pelagic fisheries by various research groups around the world. Such work would also allow more spatially accurate estimates of the cost of protecting the high seas than has been possible to date. While high seas

Table 1. Likely global loss of catches, revenue, and profit under suggested proportions of marine reserve closures of the high seas

\begin{tabular}{|c|c|c|c|c|}
\hline \multirow{2}{*}{$\begin{array}{l}\text { Proposed closure } \\
\text { size }(\%)\end{array}$} & \multicolumn{2}{|c|}{ Global catch loss } & \multirow{2}{*}{$\begin{array}{l}\text { Global revenue loss } \\
\text { (Billion US\$) }\end{array}$} & \multirow{2}{*}{$\begin{array}{l}\text { Global profit } \\
\operatorname{loss}^{\mathrm{a}}\end{array}$} \\
\hline & $\%$ & $10^{6}(\mathrm{t})$ & & \\
\hline 10 & 0.9 & 0.75 & 1.35 & 0.14 \\
\hline 20 & 1.8 & 1.50 & 2.70 & 0.27 \\
\hline 50 & 4.5 & 3.75 & 6.75 & 0.68 \\
\hline 100 & 8.9 & 7.50 & 13.50 & 1.35 \\
\hline
\end{tabular}

marine reserves are not a novel idea (e.g. Norse 2006), none have been established yet.

In the general context of ecosystem considerations, there are suggestions that at least $20 \%$ of a given fishing area or habitat type should be fully protected to primarily deal with uncertainty and risk (Lauck et al. 1998), while at the same time conserving biodiversity (Ward et al. 1999), and possibly improving or even maximizing long-term yield (Hastings \& Botsford 1999). It has even been proposed that to provide for true long-term sustainability, the seas (including the high seas) should be treated as 'closed to fishing with small exceptions (limited fishing areas and times)' (Walters 1998), and that ocean zoning should amend the existing status quo of 'freedom of the seas' with regards to resource exploitation in the high seas as established by UNCLOS (Russ \& Zeller 2003). The World Commission on Protected Areas (WCPA), for instance, also calls for 20 to $30 \%$ of all seas to be protected.

Here, we provide a first global estimate of the economic cost of removing $10,20,50$, and $100 \%$ of potential fishing areas from the high seas, based on recently developed global catch and landed value databases (Watson \& Pauly 2001, Sumaila et al. 2007). This analysis will provide for the high seas what Balmford et al. (2004) provided for a marine protected area (MPA) network for all of the world's oceans.

Potential costs of marine reserves in the high seas. An obvious disadvantage (i.e. cost) of implementing high seas marine reserves - at least in the short term - is the reduced global supply of fish, with all the negative social and economic impacts that this may entail (e.g. lost jobs). While in the medium to long term, marine reserves may contribute positively to catch levels, current economic and market principles unfortunately place premium emphasis on short-term considerations (Sumaila \& Walters 2005). Information from the 'Sea Around Us Project' (SAUP, www.sea aroundus.org) catch database (Watson \& Pauly 2001) suggests that from 1990 to 2002, an average of $8.9 \%$ of the global marine fish catch was taken from the high seas per year (given the high level of IUU fishing likely happening on the high seas, actual catches from these areas may be higher). Hence, everything else being equal, this would imply that closing 10, 20, 50, or $100 \%$ of the high seas to fishing may lead to losses of between 0.9 and $8.9 \%$ of current marine capture fisheries catch per year (Table 1). Typically, nothing actually remains equal. In this case, for instance, fishing effort may be displaced to non-protected areas, 
Fig. 1. Although the high seas (light blue) outside of the $200 \mathrm{n}$ mile Exclusive Economic Zone of maritime countries (dark blue), and excluding areas of permanent ice (grey), make up about $56 \%$ of the world ocean areas, they account for only $9 \%$ of the current marine fisheries catch

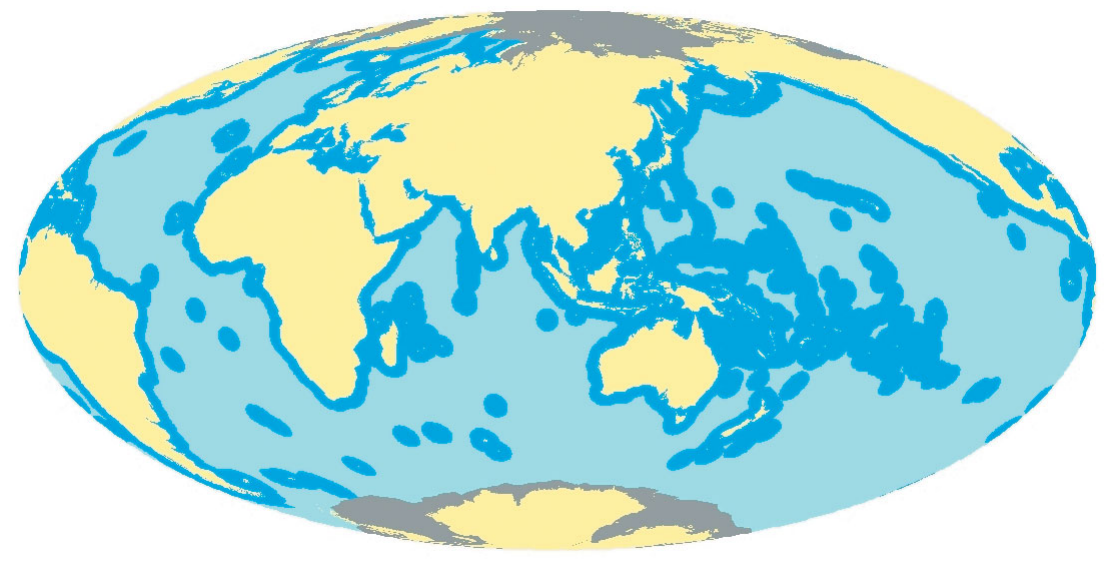

thereby reducing the potential loss in catch and landed value. This approximation assumes non-migratory and evenly spread fish in the high seas, a condition clearly not met in any high seas ecosystem. Therefore, the actual loss experienced by fisheries would be a function of species migration and optimization of MPA location, and could be less than indicated here. Importantly, any effective system of closed areas must be a representative network of closures, which, if applied, would make our approximation more realistic.

In terms of total revenue, this loss amounts to between US\$1.35 and US\$13.5 billion a year (Table 1), according to an ex-vessel global fish price and landed values database (Sumaila et al. 2007). Much of that loss would be in the tuna, swordfish, and small pelagic fisheries (Fig. 2). According to Statistics Iceland (2005), profits of 10 to $11 \%$ were recorded in 2003, while Statistics Norway (2005) reported $7 \%$ operating profits for Norway's deepwater prawn vessels and $8 \%$ for trawlers that process fish onboard in 2002. We therefore assumed that profits from other fisheries from around the world are not likely to be higher than these numbers. Thus, if we assume a realistic net return, or profit, from fishing in the high seas of $10 \%$ of landed value, then closing $20 \%$ of the high seas to fishing would result in a loss in profit of about US\$270 million per year, out of a total high seas profit of approximately US\$1.35 billion (Table 1). It is worth noting that the US\$270 million annual profit loss potentially derived from a $20 \%$ closure of all pelagic and deep sea fisheries would constitute a loss in profit that compares favorably to the estimated US\$152 million per annum

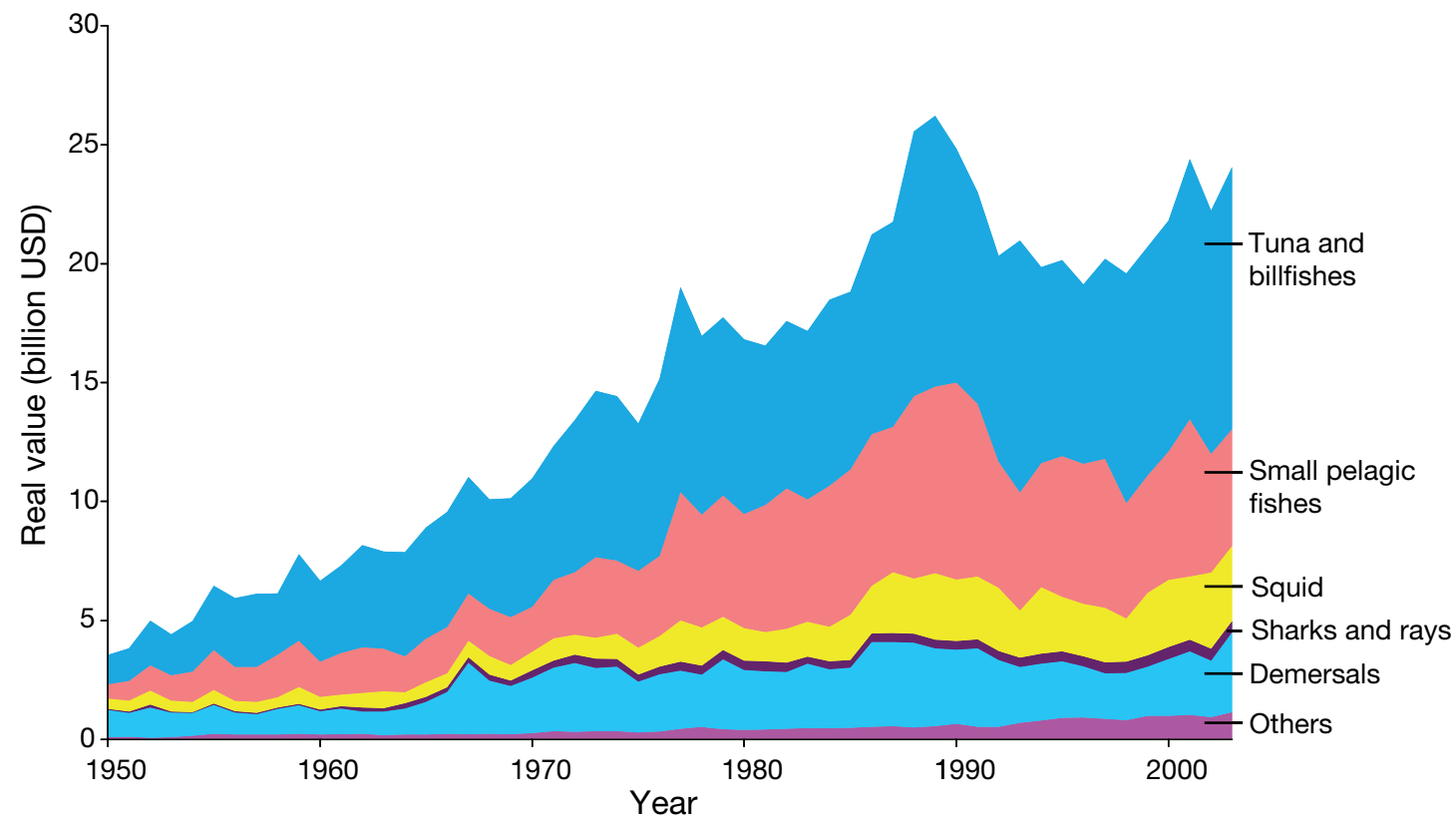

Fig. 2. Trends in the value of high seas fisheries from 1950 to 2002 for a range of marine taxa. Prices are adjusted to constant 2000 prices (Sea Around Us Project 2006) 
currently paid as subsidies by taxpayers to the high seas deep-sea bottom trawlers alone (Sumaila \& Pauly 2006).

Potential benefits of marine reserves in the high seas. Should the global community implement, for example, a $20 \%$ closure in the context of ecosystem considerations, it would receive substantial benefits in return for the loss of $1.8 \%$ of the global marine fish catch, and US\$270 million in profit (Table 1).

First, the suggested approach would reduce the possibility of overfishing marine resources in the high seas by permanently removing a part of the resource from potential exploitation or by rebuilding threatened stocks including tuna and billfish (Fig. 2). This would happen only if the effort taken out is not displaced to open areas of the high seas. In other words, permanent capacity reductions, good monitoring, control, and surveillance are necessary to ensure that this happens. Furthermore, the world community will have a better chance of preserving the non-consumptive and nonmarket values (that is, values that are not traded in the market, and include, for example, existence and bequest values) of marine resources and habitats found in the high seas, which can be quite high, and may even exceed current market values (e.g. Costanza et al. 1997).

Second, converting parts of the high seas into marine reserves would provide some insurance against management errors within fished areas (Lauck et al. 1998). Such an action is also likely to help rebuild the fish stocks in the protected areas, which will not only serve as a stock and biodiversity reservoir, but very likely enhance fishing in the non-protected parts of the high seas (Lauck et al. 1998).

Third, monitoring, control, and surveillance of the high seas, while never easy, is easier for detecting spatial use violations through the use of modern surveillance technologies, which facilitate spotting violators from remote locations. Maintaining the 'right of innocent passage' enshrined in UNCLOS can readily be accommodated via compliance with remote vessel monitoring systems that are speed sensitive and thus able to differentiate between cruising speeds used for passage through areas closed to fishing and geardependent fishing speeds. Violations of no-fishing zones can be more effectively countered through substantially increased penalty structures for what would in essence be international law-breaking (High Seas Task Force 2006), and by increasingly incorporating trade-based approaches in management (Organisation for Economic Co-operation and Development 2004). Until recently, fines for illegal fishing were much lower than the potential benefits derived from illegal fishing. However, this is changing through the creation of dedicated environmental courts and judiciary education, and more severe penalty structures. South Africa seems to be leading the way in this matter, having announced the first environmental court in 2003 (see point 5.A. at www.info.gov.za/speeches/2003/ 03021809461006.htm).

Fourth, high seas areas, especially deep slope, coldwater coral and seamount environments, include areas with highly vulnerable benthic organisms and habitats that are threatened by deep-sea bottom trawling (Devine et al. 2006). This puts not only these species and the unique habitats they create for other species in peril, but also risks their potential alternative use to humans (Watling \& Norse 1998). Many productive seamounts in the high seas support structural habitats and species such as orange roughy Hoplostethus atlanticus, which are extremely vulnerable to overfishing due to their late age of maturity and slow growth rates (Morato et al. 2005). Large-scale spatial closures would also be useful in protecting essential and sensitive fish habitats (e.g. seamounts, deep-water corals) for as yet unrealized non-consumptive use, not only for current generations but also for the benefit of future generations.

Finally, bottom trawl fleets operating in the high seas, in particular, are highly automated (thus minimizing employment) and consume a large quantity of fuel, which is subsidized by governments around the world. Sumaila \& Pauly (2006) showed that the amount of subsidies received by deep sea bottom trawlers exceeds the likely profits generated by them. Also, Gianni (2004) noted that fishing vessels flagged by 13, mostly rich countries took $>95 \%$ of the reported high seas bottom trawl catch in 2001. These points indicate that high seas bottom trawlers do not contribute much in terms of net societal benefits (profit and/or employment), and therefore society must seriously reconsider if this sector should be permitted to subject the high seas ecosystems and species to the risk of overexploitation.

Challenges to our proposal. The major obstacle to creating successful marine reserves in the high seas is that different nations and fisheries will face different costs and benefits. The key issue for countries that are already active on the high seas is the loss they will incur if marine reserves are implemented. Countries that lose more than they gain, especially in the short term, may resist the proposal. Therefore, compliance incentive schemes need to be developed that overcome resistance by such countries (Stone 1997, Sumaila 2005).

A second major challenge for the proposal is that the short-term annual losses may appear too large for many nations compared to the long-term future benefits. The well-known problem of 'instant gratification,' in economic terms commonly known as 'discounting,' may stand in the way of a proposal that is likely to 
serve humans well (Sumaila \& Walters 2005). A critical mass of visionary world leaders dealing with global fisheries problems and working with the United Nations and the G8 and G20 group of countries to develop the necessary governance and international legal and institutional structures is a way to tackle this problem.

A third challenge revolves around which areas to close. Such decisions, while ultimately politically driven, should be heavily informed by optimization approaches for economic and ecological benefits. Recent work on identifying large seamounts and clusters of seamounts globally (e.g. Kitchingman \& Lai 2004), spatio-temporal evaluations of fishing effort distribution for pelagic fisheries (e.g. R. Ahrens unpubl. data), and global modeling efforts for optimization of protected area placement in a biodiversity setting (e.g. Wood \& Dragicevic 2006) may provide the opportunity to derive quantitative and rigorous evaluations and optimization of site location for high seas MPAs.

\section{CONCLUSION}

Although creating high seas marine reserves may be controversial, the history of UNCLOS suggests that collective action can benefit the current generation and maintain high seas resources for the benefit of future generations. However, the history of past management of fishery collapses has also demonstrated that the time to act on marine reserves is now. By forgoing a relatively small fraction of current global marine capture fisheries catch by closing portions of the high seas to fishing, the global community may secure some insurance against extinctions and the loss of marine diversity in the high seas, while protecting many market and non-market values for the benefit of both current and future generations.

Acknowledgements. The support of the Sea Around Us Project, sponsored by the Pew Charitable Trusts, Philadelphia, is appreciated. U.R.S. thanks OCEANA and the European Community's program for International Scientific Co-operation (INCO). We also thank 2 reviewers and a contributing editor for their helpful comments on an earlier version of the paper.

\section{LITERATURE CITED}

Balmford A, Gravestock P, Hockley N, McClean CJ, Roberts CM (2004) The worldwide costs of marine protected areas. Proc Natl Acad Sci USA 101:9694-9697

Costanza R, D'Arge R, de Groot R, Farber S and 9 others (1997) The value of the world's ecosystems services and natural capital. Nature 387:255

Devine JA, Baker KD, Haedrich RL (2006) Deep-sea fishes qualify as endangered. Nature 439:29
Gianni M (2004) High seas bottom fisheries and their impact on the biodiversity of vulnerable deep-sea ecosystems: Summary findings. International Union for Conservation of Nature \& Natural Resources. Available at: www.iucn. org/themes/marine/pdf/MattGianni-CBDCOP7-ImpactHS-BottomFisheries-Complete.pdf\#search=\%22Gianni $\%$ 20high $\% 20$ seas $\% 22$

Gjerde KM, Freestone D (2004) Unfinished business: deepsea fisheries and the conservation of marine biodiversity beyond national jurisdiction: Editors' introduction. Int J Mar Coast Law 19:209-222

Hardin G (1968) The tragedy of the commons. Science 162: 1243-1248

Hastings A, Botsford LW (1999) Equivalence in yield from marine reserves and traditional fisheries management. Science 284:1537-1538

High Seas Task Force (2006) Closing the net: stopping illegal fishing on the high seas. Governments of Australia, Canada, Chile, Namibia, New Zealand, and the United Kingdom, WWF, IUCN, and the Earth Institute at Columbia University

Kitchingman A, Lai S (2004) Inferences of potential seamount locations from mid-resolution bathymetric data. In: Morato T, Pauly D (eds) Seamounts: biodiversity and fisheries. Fisheries Centre Research Report 12, University of British Columbia, Vancouver, p 7-12

Lauck T, Clark CW, Mangel M, Munro GR (1998) Implementing the precautionary principle in fisheries management through marine reserves. Ecol Appl 8:S72-S78

Lodge MW (2004) Improving international governance in the deep sea. Int J Mar Coast Law 19:299-316

Morato T, Cheung WWL, Pitcher TJ (2005) Vulnerability of seamount fish to fishing: fuzzy analysis of life-history attributes. J Fish Biol 67:1-13

Myers RA, Worm B (2003) Rapid worldwide depletion of predatory fish communities. Nature 423:280-283

Norse EA (2006) MPA Perspective. Protecting the leastprotected places on earth: the open oceans. MPA News Vol 7(7), Marine Conservation Biology Institute, Bellevue, WA, USA

Organisation for Economic Co-operation and Development (OECD) (2004) Fish piracy: combating illegal, unreported and unregulated fishing. OECD, Paris

Pauly D, Christensen V, Guénette S, Pitcher TJ, Sumaila UR, Walters CJ, Watson R, Zeller D (2002) Towards sustainability in world fisheries. Nature 418:689-695

Russ GR, Zeller D (2003) From Mare Liberum to Mare Reservarum. Mar Policy 27:75-78

Sea Around Us Project (2006) Fisheries database. Available at http://www.seaaroundus.org

Statistics Iceland (2005) Profitability in fishing and fish processing 2003. Available at: www.statice.is/lisalib/getfile. aspx? ItemID $=975$

Statistics Norway (2005) Operating results of whole-year operated fishing vessels 13 meters and more, by fishery. Average per vessel, 2002. Available at: www.ssb.no/english/subjects/10/05/nos_fiskeri_en/arkiv/nos_d321_en/tab /tab-52.html

Stone CD (1997) The crisis in global fisheries: can trade laws provide a cure? Environ Conserv 24:97-98

Sumaila UR (2005) Differences in economic perspectives and the implementation of ecosystem-based management of marine resources. Mar Ecol Prog Ser 300:279-282

Sumaila UR, Pauly D (eds) (2006) Catching more bait: a bottom-up re-examination of global fisheries subsidies. Fisheries Centre Research Report 14, University of British Columbia, Vancouver 
Sumaila UR, Walters C (2005) Intergenerational discounting: a new intuitive approach. Ecol Econ 52:135-142

Sumaila UR, Marsden D, Watson R, Pauly D (2007) Global exvessel fish price database construction, spatial and temporal applications. J Bioecon 9:39-51

United Nations (UN) (2005) Oceans and the law of the sea. Report of the Secretary-General. Addendum. A/60/63/Add.1. United Nations General Assembly, New York

Walters C (1998) Designing fisheries management systems that do not depend upon accurate stock assessment. In: Pitcher T, Hart PJB, Pauly D (eds) Reinventing fisheries management. Kluwer Academic Publishers, London, p 279-288

Editorial responsibility: Konstantinos Stergiou (Contributing Editor), Thessaloniki, Greece
Walters CJ (2003) Folly and fantasy in the analysis of spatial catch rate data. Can J Fish Aquat Sci 60:1433-1436

Ward TJ, Vanderklift MA, Nicolls AO, Kenchington RA (1999) Selecting marine reserves using habitat and species assemblages as surrogates for biological diversity. Ecol Appl 9:691-698

Watling L, Norse EA (1998) Disturbance of the seabed by mobile fishing gear: a comparison to forest clearcutting. Conserv Biol 12:1180-1197

Watson R, Pauly D (2001) Systematic distortions in world fisheries catch trends. Nature 414:534-536

Wood LJ, Dragicevic S (2006) GIS-based multicriteria evaluation and fuzzy sets to identify priority sites for marine protection. Biodivers Conserv 16:2539-2558

Submitted: September 28, 2006; Accepted: May 22, 2007 Proofs received from author(s): September 5, 2007 